\title{
Stanniocalcin 2 (STC2) Expression Promotes Post-Radiation Survival, Migration and Invasion of Nasopharyngeal Carcinoma Cells [Corrigendum]
}

He H, Qie S, Guo Q, et al. Cancer Manag Res. 2019;11:6411-6424.

On page 6421 , Figure $7 \mathrm{C}$. It was brought to the authors attention that a control micrograph was inadvertently placed into the experimental group in Figure 7 panel $\mathrm{C}$ during figure preparation. The authors have re-checked the original records and data analysis process and determined that the general conclusion of the study was not affected by this error. The authors apologize for this error.
C

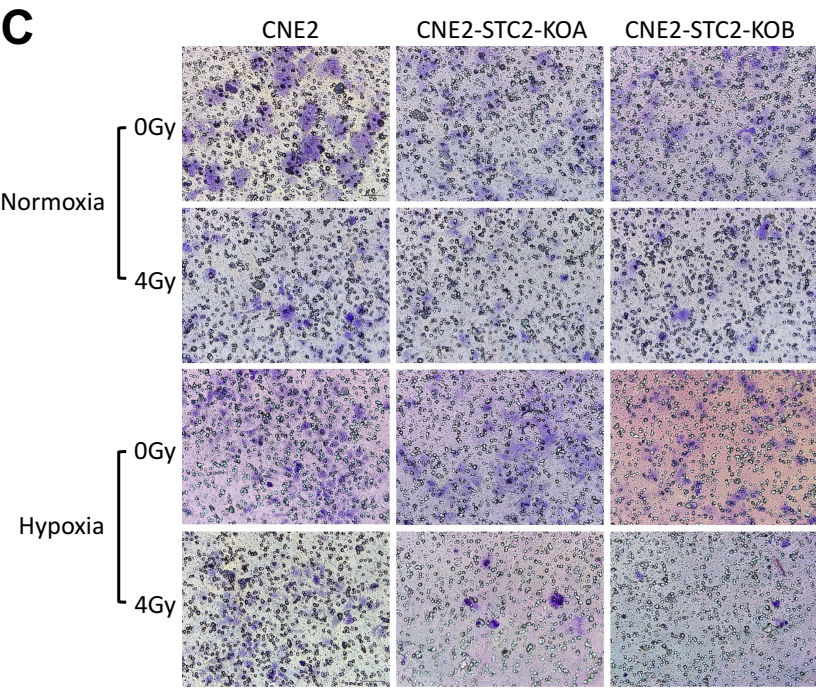

Cancer Management and Research

\section{Publish your work in this journal}

Cancer Management and Research is an international, peer-reviewed open access journal focusing on cancer research and the optimal use of preventative and integrated treatment interventions to achieve improved outcomes, enhanced survival and quality of life for the cancer patient.

\section{Dovepress}

The manuscript management system is completely online and includes a very quick and fair peer-review system, which is all easy to use. Visit http://www.dovepress.com/testimonials.php to read real quotes from published authors. 